\title{
SZAKÁLY ZSOLT
}

\section{A FITTSÉG ÉLETKOR-SPECIFIKUS VIZSGÁLATÁNAK JELENTŐSÉGE THE IMPORTANCE OF AGE-SPECIFIC FITNESS TESTING}

Széchenyi István Egyetem, Egészség- és Sporttudományi Kar, Győr

\begin{abstract}
Absztrakt
A fittség egy olyan testi-lelki állapot, amely magába foglalja az egészséges testi felépítést és testösszetételt, a megfelelő fizikai teljesítőképességet, alapot biztosít a jó közérzet kialakításához és megtartásához. A fittségi állapot rendszeres testmozgással, egészséges táplálkozással fejleszthető és tartható fenn.

A humánbiológiai jellemzők, a motorikus képességek az egészségi állapotunk lényeges elemei, melyek a genetikai adottságokra épülve az életmódhatások sajátos szinergiájában alakulnak ki az egyedfejlődés során.

Az egészséges gyermekeknél vagy felnőtteknél a genetikai meghatározottság soha nem eredményez túlsúlyt vagy elhízást. A testösszetétel életünk során érzékenyen "reagál" a megváltozott környezeti hatásokra. A mozgásszegény életmód, a helytelen táplálkozás károsan befolyásolja az aktuális testösszetételt, melynek következménye többek között a zsír- és az izomtömeg optimális arányának felbomlása.

A motorikus teljesítmények eltérő mértékben ugyan, de szintén genetikailag meghatározottak, azonban különböző mértékben, de fejleszthetők. Az egyén motorikus képességeinek fejlődését-fejlesztését, optimális szinten tartását a biológiai és környezeti tényezők egyaránt befolyásolják.

Az életkörfüggő növekedés, fejlődés és érés, valamint ezzel összefüggésbe hozható fizikai/fittségi teljesítményszint-változás korosztályfüggő vizsgálata központi feladata a testnevelés- és sporttudománynak.

Evidenciának tűnik, hogy a fittségi állapot fejlesztésének lehetősége az életkor függvényében csökken, e csökkenés azonban rendszeres fizikai aktivitással lassítható.
\end{abstract}

Kulcsszavak: fittség, életkor-specifikus, motorikus képességek, életmód, 


\begin{abstract}
Fitness is a physical and mental state that includes a healthy physique and body composition, adequate physical performance, and a basis for developing and maintaining well-being. Fitness can be developed and maintained through regular exercise and healthy eating. Human biological characteristics, motor abilities, are essential elements of our health, which, based on genetic traits, develop in a unique synergy of lifestyle effects during individual development.

In healthy children or adults, genetic prediction will never lead to overweight or obesity. The body composition is ,responsive' to changed environmental influences throughout our lives. A sedentary lifestyle and poor nutrition adversely affect the actual body composition, resulting in, among other things, the breakdown of the optimal ratio of fat and muscle mass.

While motor performance is genetically determined to varying degrees, it can be improved to varying degrees. The development and maintenance of an individual's motor abilities are influenced by biological and environmental factors.

Age-dependent examination of life-dependent growth, development and maturation, and related changes in physical / fitness performance, is a central concern of physical education and sports science. Evidence suggests that the ability to improve fitness depends on age, but this decline can be slowed by regular physical activity.
\end{abstract}

Keywords: fitness, age-specific, motoric abilities, lifestyle 


\section{Bevezetés}

A fittség egy olyan testi-lelki állapot, amely magába foglalja az egészséget, a megfelelő fizikai teljesítőképességet, és lehetővé teszi a jó közérzet kialakítását, megtartását. A fittségi állapot a rendszeres testmozgással, az egészséges táplálkozással, valamint az egészséget károsító magatartásformák kerülésével fejleszthető és tartható fenn.

Az életkörfüggő fejlődés és érés, valamint az ezzel összefüggésbe hozható fizikai/fittségi teljesítményszint-változás vizsgálata központi feladata a testnevelés- és sporttudománynak, az iskolai és iskolán kívüli testnevelésnek és a humánbiológiának is (Konczos et al., 2006). A növekedés, fejlődés és érés folyamatai nagyon plasztikusak, a fiatal felnőttkorban jellemző morfológiai és funkcionális tulajdonságok a többségében laza vagy mérsékelt erősségü genetikai meghatározottság mellett a külső környezet állandó befolyása (egészséges táplálkozás és fizikai aktivitás) alatt alakulnak ki (Post et al., 1997; Rankinen et al., 2001; Beunen, 2003).

Az utóbbi évtizedekben a gazdasági és társadalmi fejlődés eredményeként az általános iskolai tanulók generációspecifikus antropometriai paraméterei általánosságban pozitív irányba változtak (Bodzsár, 1998; Tóth és Eiben, 2004). Ezzel szemben a fizikai/motorikus teljesítmények színvonala romló tendenciát mutat (Rowland, 2003). A probléma számos aspektusának legújabb összefoglalása már egyetemi tankönyvbe is bekerült hazánkban (Bedros, 2017). A kutatási eredmények alapján az általános iskolás korú tanulóknál egy negatív irányú motorikus fejlődés alakult ki (Photiou et al., 2008). E jelenségek oka többek között az életszínvonal emelkedése, ami a táplálkozási szokásokat megváltoztatva túlzott energiabevitelt eredményezett (Bognár és mtsai., 2010). Párhuzamosan ezzel megjelent mozgásszegény életmód, ami csökkent energiafogyasztást hozott létre (Telama és Yang, 2000; Ross et al., 2000). A jelenségről, illetve megelőzésének és kezelésének lehetőségeiről Molnár és munkatársai (2017), valamint Túri és kutatócsoportja (2017) számoltak be.

A gyermekeknél, különösen a prepubertásban és a pubertásban a testi felépítés, a szervek és szervrendszerek müködésének összhangja igen fontos, ami egyben kifejeződik a motorikus teljesítmények szintjében is. Ezért a fittségi szint rendszeres vizsgálata és elemzése kiemelkedő jelentőségű különösen a gyermekek és serdülők esetében a szomatikus fejlettség meghatározásában, a felnőttek esetében elsősorban az egészségi állapot jellemzésében.

Népegészségügyi szempontból is fontos kutatási terület a „Mindennapos Iskolai Testnevelés" (MIT) bevezetésének hatásvizsgálata, különösképpen az iskoláskorúak antropometriai paramétereinek és motoros teljesítményének tekintetében. A fittségi vizsgálatoknak nemcsak az iskoláskorúak, hanem a felnőtt lakosság is kiemelt célcsoportja kell hogy legyen (Tánczos és Bognár, 2019). Az egészségi állapot és a fittségi jellemzők minden életkorban iránymutatók, és segítik az egészséges életmód fenntartását, az egészségnevelés céljainak a kitüzését. 


\section{Gyermekek, serdülők fittségi állapotának jellemzői}

Szakály és Búza (1994) a szakmunkás- és szakközépiskolai tanulók alkati és testösszetétel-jellemzőit, valamint a Cooper-tesztben nyújtott teljesítményüket vizsgálta. Azt tapasztalták, hogy a serdülőkorú tanulók fizikai felkészültsége, különösen a szakmunkástanulóké nagyon gyenge volt. 109 tanulóból csak 9 teljesítménye esett a "jó" kategóriába, míg 45 tanuló eredménye volt a gyenge csoportba sorolható. Az antropometriai jellemzőik is jelentős szórást mutattak. A lehetséges okként megfogalmazták, hogy szakmunkástanulók ingerszegényebb környezetből kerülnek ki, a fizikai aktivitás nem játszik életvitelükben jelentős szerepet, a sportteljesítmény számukra nem jelent értéket. Ez a sajnálatos felfogás megjelenik fizikai teljesítményükben és rányomja bélyegét életmódjukra is.

Szakály és Pozsgai (2000) vizsgálatuk során azt tapasztalta, hogy a középiskolába felvételiző gyermekek fizikai teljesítményei elmaradnak a 15-20 évvel korábbi gyermekek átlagaihoz képest. Az általunk becsült oxigénfelvétel átlagai a fiziológiásan elvárt tartományok alsó határán mozogtak. A jelentős szórások arra utaltak, hogy a képesség fejlettsége tanulónként és tanulócsoportonként is nagyon eltérő volt. Magyarázatként a biológiai fejlődésből adódó különbségeket, illetve az általános iskolai testnevelés különbözőségeit (hatékonyság) jelölték meg. A következtetésükben megfogalmazták, hogy az átlagok és a jelentős szórások pedagógiai problémaként kezelendők, ami a felzárkóztatást és a differenciálást helyezi előtérbe. Megfogalmazták továbbá, hogy a vizsgálat tapasztalatai az általános iskola hagyományaira és a testnevelésórák hatékonyságára is engednek következtetni.

Ihász és munkacsoportja (2005) a serdülőkor előtti korosztályokra vonatkozó vizsgálati eredmények elemzése után megfogalmazta, hogy a testösszetétel kedvezőtlen irányú változása és a motorikus teljesítmények konzekvens romlása kimutatható a korábbi évtizedek vizsgálati eredményeihez képest. Az okok detektálása során rámutattak az életmódváltozás elsődleges szerepére, gyakorlatilag kizárva a genetika tényezők esetleges befolyásoló hatását.

Szakály (2008) 7-14 éves fiú korosztály (Győr város) antropometriai jellemzőinek és motorikus teljesítményeinek változását vizsgálta, figyelembe véve a vizsgálati időszakot megelőző társadalmi és gazdasági folyamatokat/változásokat. A kutatási eredmények értelmezése után egyértelműen megfogalmazódott, hogy az ezredfordulót követően vizsgált győri általános iskolás fiúk antropometriai és motorikus teljesítményjellemzőiben egyaránt felismerhetők a nemzedéki különbségként értelmezendő differenciák és az életmód anomáliáira visszavezethető negatív jelenségek. A szekuláris trend következménye a vizsgált korcsoportok korábbiaknál magasabb termete és testi felépítésük linearizálódása. Megállapították, hogy a győri fiúk testtömegszázalékban kifejezett testzsírtartalma nagy volt. A nagy depózsírmennyiség a megváltozott életmód következménye. A nagy testzsírtartalom és az ehhez vezető életmód kielégítően magyarázta a vizsgált fiúk átlagosan nagyon mérsékelt motorikus teljesítményét is. 
A fent szemlézett vizsgálatok, és a pedagóguspályán szerzett gyakorlati tapasztalatok indukálták Király és Szakály (2011) munkáját. A szerzők felismerve a tudatos mozgásfejlesztés jelentőségét, új szemléletűen foglalták össze tapasztalataikat. A gondolatuk középpontjában a személyiségfejlesztés, annak is az úgynevezett "holisztikus" megközelítése állt. A szerzők megfogalmazták: ha elfogadjuk azt, hogy a mozgásfejlődés egységes folyamat, akkor a szakemberek képzésében is jelentkeznie kell egyfajta „központosított” gondolatmenetnek, annak ellenére, hogy a szakemberek képzése különböző képzési szinteken történik: óvó-, tanító-, tanár-, edző-, valamint a rekreációs képzés.

Ihász és munkatársai (2012) az intervenciós programok hatását vizsgálták Győr város három iskolájában. A kutatás központi kérdése az volt, hogy a tanulói tudatosság növelése hogyan befolyásolja a motorikus teljesítmények változását. A vizsgálatban részt vevő kollégák feladata volt olyan motivációs, érdekeltségi rendszer kialakítása, melynek eredményeként a tanulók önálló sporttevékenységet végeztek szabad idejükben. Az önálló tevékenység során a gyermek megtanulta a pulzusmérő óra használatát, megismerte a futáshoz szükséges és elégséges intenzitást, az egy kilométer lefutásához szükséges optimális sebességet. Ennek megfelelően a felmérés nem cél, csak egy eszköz volt arra, hogy a tanuló tájékozódhasson a saját állapotának fejlődéséről. A kutatás során bebizonyosodott, hogy ha testnevelési "házi feladattal” kíséreljük meg a szükséges szabadidős szokások kialakítását, az szinte minden korosztályban pozitív hozzáállást eredményez a tanulóknál, ami a fizikai teljesítményeket is javítja. Következtetésként megállapították, hogy a módszer alkalmas arra, hogy bevonja a tanulókat saját fejlesztésükbe, mely folyamatot már első osztályban el kell kezdeni annak érdekében, hogy mire a tanulók felső tagozatba, majd középiskolába kerülnek, megfelelő tapasztalattal és attitűddel rendelkezzenek.

A Magyar Köztársaság Kormánya 2011/2012-es tanévben konkrét lépéseket tett a mindennapos testnevelés bevezetésének érdekében. A mindennapos testnevelés hatásának vizsgálata természetesen a bevezetés óta eltelt idő rövidsége miatt nem teljesen releváns, azonban kutatócsoportunk véleménye szerint az eltelt idő már elegendő arra, hogy bizonyos változások kimutathatók legyenek. Szakály és munkatársai $(2015,2016)$ a mindennapos testnevelés hatásának vizsgálatára koncentráltak helyi és regionális mintákon. A kutatók megállapították, hogy a mindennapos iskolai testnevelés bevezetése korosztály-specifikus hatást fejtett ki a 7-14 éves győri fiú tanulók $\left(\mathrm{n}_{2010}=562 ; \mathrm{n}_{2016}=\right.$ 551) szomatikus fejlődésre (antropometriai paraméterek és motorikus teljesítmények). A mindennapos iskolai testnevelés bevezetése általánosságban javította a testtömeg-index (BMI) és a 10-11 éves korú tanulók derék-csípő arányát, továbbá jelentősen fokozta a 7-8 évesek állóképességi mutatóit. A mindennapos testnevelés azonban nem javította a 7-9 és 12-14 éves tanulók derék-csípő arányát és a 11-14 éves tanulók állóképességi mutatóit.

Malina és Bouchard (1991) tapasztalata szerint az egészséges és kiegyensúlyozott gyermekfejlődést stimuláló fizikai aktivitás (elsősorban aerob intenzitású munkavégzés) napi gyakorisággal minimálisan 60 perc, de kedvezőbb, ha a 
terjedelem eléri a másfél órát! Gyermekeink többségének fizikai aktivitása ezt a mennyiséget a mindennapos testnevelés bevezetése előtt meg sem közelítette (Mészáros et al., 2006).

\section{Fittségi vizsgálatok tapasztalatai felnőtteknél}

A XX. század utolsó harmadától kezdődően az életszínvonal és az életmód együttes változása azt eredményezte, hogy csökkent a gyermekek, a serdülőkorúak és a felnőttek fizikai teljesítőképessége, és értékelhetően nőtt a testtömegszázalékában kifejezett testzsírtartalma (Bouchard, 2000; Rurik et al., 2016).

Gáldi (2002) a magyar lakosság átfogó statisztikai adatainak elemzése alapján megállapította, hogy a 15-84 év közötti lakosság mindössze 30\%-a végez rendszeres sporttevékenységet, az életkor emelkedésével a sporttevékenységet folytatók aránya szinte lineárisan csökken. A tanulmány arra is rámutat, hogy az iskolai végzettség emelkedésével együtt nő a fizikai aktivitás gyakorisága.

A felnőtt korosztállyal kapcsolatos vizsgálataink során kutatócsoportunk az antropometriai jellegek és a motorikus tulajdonságok vizsgálata mellett fontosnak ítélte meg a fizikai aktivitással kapcsolatos motivációk és attitűdök vizsgálatát is. A kutatási terület kiszélesítése megkerülhetetlen volt, hiszen a vizsgált mintánk jellemzően az egyetemi-főiskolai hallgatókra (tanító, testnevelés és rekreáció szakos) koncentrált, hiszen az ő feladatuk lesz az egészséggel kapcsolatos magatartásminták átszármaztatása a különböző korosztályokra.

Szakály és munkacsoportja a 2000-es évek elejétől vizsgálta a fent említett korosztályt, és megállapította, hogy az általuk vizsgált hallgatóknál (tanító szakos, szociálpedagógus, művelődésszervező) mind a kardiorespiratorikus rendszer, mind az elhízás rizikófaktorai megtalálhatók, melyek előrevetítik az egészségi állapot kedvezőtlen változásait (Szakály, 2002; Szakály et al., 2003). A problémát tovább súlyosbítja, hogy a felsőoktatásból kikerülő tanítók, szociálpedagógusok és művelődésszervezők fontos feladata lesz az egészségnevelés, az egészséges életmód igényének a kialakítása, amihez családi példamutatás mellett pozitív személyes mintaadás szükséges (Olvasztóné és mtsai,, 2007). Tapasztalatunk az, hogy a felsőoktatásban a hallgatókat csak akkor érdemes és szabad feloldani a kötelező testedzés alól, ha az infrastrukturális feltételek optimálisak, a hallgatók motiváltak, valamint a kínálat és a diákok részéről a kereslet megegyezik.

Szakály és munkacsoportja (2007) követéses vizsgálat során elemezte felsőfokú tanulmányok befejezése után közvetlenül, majd négy év múlva a végzett hallgatók motorikus teljesítményeit és antropometriai jellemzőit. A négy év távlatában a vizsgált személyek fizikai aktivitásának a gyakorisága szinte nullára csökkent. Ennek következtében markáns változást tapasztaltunk, ami érintette a fizikai teljesítmény csökkenése mellett a testösszetétel szignifikáns változá- 
sát is. Az eredmények elgondolkodtatók, hiszen a felsőoktatás az utolsó olyan szervezett nevelési szintér, amely hatékonyan használható fel az egészségnevelés céljainak a megvalósításában.

Számos kutatócsoport tapasztalata az, hogy a jól tervezett és szervezet fizikai aktivitást is tartalmazó intervenciós programok javítják a vizsgált személyek motivációját, sokszor az attitűdjét is (Konczos et al., 2011; Konczos et al., 2016). Megfogalmazható tehát, hogy szükséges a kor követelményeinek megfelelő pedagógiai színvonalú és tudatosan tervezett testnevelés a felsőoktatásban is. A pszichés képességek és a megfelelő hozzáállás fejlesztése mellett a testnevelő tanároknak meg kell tanítani a hallgatóknak, és a hallgatóknak meg kell tanulniuk az életvitelük egészségtudatos tervezését és kialakítását. E gondolatkörben fel kell hívni a figyelmet arra, hogy a személyiség teljes és kiegyensúlyozott fejlődése és kibontakozása érdekében minden iskolatípusban mindenki számára lehetővé kell tenni az olyan testkulturális értékek elsajátítását, melyek a gyakorlatban rendszeres tevékenységet határoznak meg (Huszár és Bognár, 2006).

A rendszeresen végzett rekreációs sporttevékenység jelentős mértékben csökkentheti a mortalitást és a morbiditást. Preventív hatású a különböző szerveket, szervrendszereket érintő megbetegedésekre, és jótékony hatása nem kérdőjelezhető meg a pszichés funkciók tekintetében sem (Vuori, 2004; Tammelin et al., 2003; McKechine és Mosca, 2003; Zhang et al., 2004). Számos vizsgálat igazolta, hogy a fizikai aktivitás csökkenti a depresszió kialakulásának kockázatát is (Vuori, 1998, Wyshak, 2001).

\section{Az idősek fittségi állapota}

Magyarország népessége 1980-as évek óta változó intenzitással, de folyamatosan csökken, azonban az idős emberek száma szignifikánsan növekszik. A fejlett európai országokhoz hasonlóan Magyarország számára is az egyik legnagyobb demográfiai (és gazdasági) kihívás a társadalom öregedése. A tartósan alacsony termékenységgel és a várható élettartam emelkedésével a gyermekkorúak aránya csökken, miközben az idősebb korosztályoké nő, így az aktív korosztályokra egyre nagyobb időskorú eltartási teher nehezedik (KSH, 2016).

Biológia aspektusból vizsgálva az idősek számának a növekedése pozitív folyamat, azonban következményeiben már egy kissé árnyaltabb a kép. A szociális intézményekben gondozottak száma évről évre növekszik, ami jelentős gazdasági terhet ró az államra (Vécseyné, Plachy, Bognár, 2008). Az időskorra jellemző az önállóság elvesztése vagy csökkenése (fizikai és mentális függetlenség), ami nemcsak az egyén, hanem a családok számára is elsősorban lelki, az állam számára főleg gazdasági nehézségeket okoz (Olvasztóné és mtsai., 2012). Az egészségügyi és szociális dolgozók számára az idősek gondozása nagy kihívást jelent. 
Az élettel való elégedettség egyik meghatározója a munkában, a magánéletben vagy akár a hobbiban, sportban való sikeresség és hasznosság érzése. Az egyéni és társadalmi hasznosság szubjektív megítélése fontos eleme a lelki egészségnek. A magyar lakosság több mint fele inkább tartalmasnak tekinti tevékenységeit, mint sem. A nők átlagosan tartalmasabbnak értékelik tevékenységeiket, mint a férfiak. Életkor szerinti bontásban a 16-34 éves fiataloknál a legmagasabb, a 35-54 évesek körében átlagos, míg az idősebb korcsoportokban a legalacsonyabb a tevékenységek tartalmasságának szubjektív megítélése.

Az idősödés folyamata során az egyén jelentős biológiai változásokon megy keresztül, melyek a mentális tulajdonságok és képességek mellett a testösszetételét és ezzel párhuzamosan a fizikai teljesítményeit is hátrányosan érintik. Az egészséges életmód, melynek szerves összetevője az egészséges táplálkozás és a rendszeres fizikai aktivitás, bizonyítottan lassítják az öregedési folyamatokat (Poon, Chodzko-Zajko és Tomprowski, 2006; Majercsik, 2008; Salem et al., 2009).

Az öregedési folyamatokkal járó negatív változások és az ebből adódó társadalmi kihívásoknak való megfelelés szükségszerűen létrehozta az úgynevezett "Active Ageing" fogalmát, gondolatkörét. Az "Active Ageing" nemcsak a fizikai aktivitás képességének a fenntartását, hanem a szociális, a gazdasági, a kulturális és a civil életben való aktív részvételt (mentális egészség) is jelenti. Az időskori demencia prevenciójában fontos szerepet kap a munka, a szellemi és a fizikai aktivitás. Hasonlóan a tartósan munkanélküliekhez, az inaktív nyugdíjasok is többször keresik fel a háziorvost, és sokkal többet költenek gyógyszerre, mint dolgozó társaik. A munka vagy az egyéb tevékenységek hiánya pszichés eredetű megbetegedésekhez vezethetnek.

Kopkáné és munkatársai (2013) kutatási eredményei igazolták azokat a fenti megállapításokat, melyek az életmód meghatározó szerepét hangsúlyozzák. A munkacsoport idősek rendszeres fizikai aktivitásra adott fiziológiai, mentális reakcióit és adaptációját vizsgálta egy 6 hónapos intervenciós program során. $A$ vizsgálat résztvevőinek önbevallása szerint a program hatására pozitív irányba változott a fizikai aktivitásuk gyakorisága és a táplálkozási szokásaik is. Javult az egészségi állapot szubjektív érzése, csökkent a rendszeren szedett gyógyszerek mennyisége és a hangulati, valamint a közösségi élményt vizsgáló mutatók is kedvező irányba változtak. A kontrollcsoport estében romlott az egészségi állapot, a fittségi mutatók, a depresszió mértéke is.

A fizikai inaktivitás szoros kapcsolatban van a legtöbb időskori betegséggel, kiemelten a mozgásfunkciók és az önellátási képesség csökkenésével, ezért az idősek számára is fontos a kornak és képességszintnek megfelelő rendszeres fizikai aktivitás, illetve az izmok „átmozgatása” (Mészárosné, 2008). Bizonyított, hogy a közösségben végzett rendszeres fizikai aktivitás az idősek egészségügyi, motorikus, pszichés és mentális funkcióromlását lassítja, az elesések száma csökkenthető, és az életminőség javítható (Székács, 2005; Iván, 2008; Bilotta et al., 2011). Ide tartozik az a tény is, hogy a fittség, az erő, az állóképesség, az 
ízületi mozgékonyság is javítható, így a prevenció hatásrendszere is erőteljesen megjelenik a folyamatban (Cress, 2006). Az idősek esetében az erőfejlesztés pozitív hatást gyakorol a zsírmentes testtömegre, az állóképességi edzés pedig kedvezően alakítja a testösszetételt (Binder et al., 2005).

Az idősek egészségi állapota, fittségi állapota, testösszetétele és életminősége szoros összefüggést mutat a különféle betegségekkel és fogyatékossággal, ezért együttesen vizsgálandók és kezelendők. Az egészségtudatosságnak és a fizikailag aktív egészségmagatartásnak jelentős szerepe van az aktív időskor kialakításában, az időskor adta lehetőségek pozitív megélésében (Iván, 2002).

\section{Összefoglalás, javaslatok}

Az egészség és a fittség fentartható, fejlesztése tanítható. Az iskolai testnevelésnek és sportnak tulajdonított pozitív hatások felismerésével párhuzamosan felértékelődött az iskoláskorúak testi fejlődésére és egészségére gyakorolt pedagógiai hatások jelentősége is (Pál, Császár, Huszár, Bognár, 2005). A testnevelésórákon átélt pozitív élmények, a személyiségformáló hatásokon túl, az aktív életmódhoz szükséges attitűdöket is erősítik (Mikulán, 2013). A tanulók szabadidő-eltöltési szokásait vizsgáló felmérések azt mutatják, hogy az iskolai testnevelés és sport az iskoláskorúak jelentős részénél az egyetlen lehetőség a rendszeres és adekvát intenzitású fizikai aktivitásra (Strong et al., 2005; Halmai és Németh, 2010). A WHO ajánlása szerint a gyermekeknek naponta 60 perces rendszeres fizikai aktivitásra lenne szükségük az egészséges biológiai fejlődés elősegítése érdekében.

A mindennapos iskolai testnevelés tantervszintű megjelenése egyrészt hosszú távú pedagógiai és szakmai fejlődési lehetőséget, másrészt rövid távon komoly módszertani és tartalmi kihívást is magában foglal (Ennis, 2013). Ericsson és Karlsson (2014) tapasztalata az, hogy hosszabb távon a rendszeres, a szervezett, a megfelelő tartalomra és módszertanra épülő testnevelés mindenképpen pozitív pszichoszomatikus hatást fejt ki. Mura és kutatócsoportja (2014) azonban arra hívja fel a figyelmet, hogy a mindennapos iskolai testnevelés csak akkor hatásos, ha az egyszerü, élvezetes, motiváló, kevés anyagi ráfordítást igényel, valamint eléri a megfelelő terjedelmet és a korfüggő közepes vagy szubmaximális intenzitást.

Az iskola az egyik legfontosabb nevelési színtér, ahol a nevelői minta és az egyéni képességekre és érdeklődésre irányuló testnevelés tanítási-tanulási folyamaton keresztül az egészségtudatos szokásrendszerek, normák és attitűdök kialakítására kiváló lehetőség adódik. A mindennapos iskolai testnevelés fontos prevenciós és nevelési eszköz is, és egyúttal segíti a NAT (2012) által hangsúlyozott élethosszig tartó egészségtudatos, aktív életvezetésre való szocializálódást és az életminőség fejlesztését (Fügedi et al., 2016). A mindennapos testnevelés optimális hatásrendszereinek kialakítása érdekében meghatározó szerepe van makroszinten a társadalmi elvárásnak és támogatásnak, míg mik- 
roszinten az iskola, a szülő és a barátok támogatásának, hozzáállásának, valamint a jól működő tanár-diák kapcsolatnak (Shephard és Trudeau, 2000; Feith et al., 2016).

A társadalom folyamatosan öregszik, ezzel párhuzamosan a szomatikus és a pszichés megbetegedések gyakorisáságának a növekedése az idősek mellett egyre nagyobb mértékben az aktív felnőtt lakosságot is érinti. Az egészségügyi és gazdasági probléma kezelése össztársadalmi érdek és feladat. Az intervenció hatékony módja lehet a felnőttek esetében a munkahelyi egészségfejlesztés. A munkahelyi egészségfejlesztés a munkáltatók, a munkavállalók és a társadalom közös érdeke és feladata, aminek célja az emberek egészségének és jólétének javítása. A cél elérése érdekében szükséges a munkakörnyezet javítása, a munkavállalók egészséges tevékenységekben való részvételének támogatása, a rugalmas munkaidő és munkahelyek biztosítása, a munkavállalók számára az egész életen át tartó tanulás lehetőségének biztosítása, sportversenyek és sportesemények szervezése, az egészséges táplálkozás ösztönzése, a dohányzásról való leszokást segítő programok biztosítása és a mentális jólét támogatása (Európai Munkahelyi Biztonsági és Egészségvédelmi Ügynökség, 2010).

A „boldog élet - boldog időskor" nem az időskorban kezdődik, hanem az egészségben való megöregedés szükséges hozzá. Az időskori boldogság egyik feltétele az egészségi állapot megőrzése. A nemzetközi szakirodalom számos hatékony modellt kínál, melyek közös jellemzője, hogy a fizikai aktivitást kiemelt jelentőségúnek ítélik meg. További determináns a jó egészségügyi ellátórendszer, szociális oldalról kiemelt jelentősége van a közösségi, társas lét megőrzésének.

A cikkben bemutatott vizsgálatok eredményei rámutattak arra, hogy a társadalmi változások/hatások és az egyén és/vagy csoport kapcsolatrendszerét érintő epidemiológiai, valamint a neveléssel-oktatással-képzéssel kapcsolatos vizsgálatok csak akkor értelmezhetők hatékonyan, ha a társadalom- és a természettudomány kiegyensúlyozottan jelenik meg a kutatási folyamatokban. Az általunk felvázolt és vizsgált problémák megoldásának a keresése tehát csak az interdiszciplináris vagy holisztikus gondolkodás középpontba állításával lehetséges.

\section{Felhasznált irodalom}

Bedros J. R. (ed.) (2017): Klinikai Obezitológia. Egyetemi Tankönyv, Semmelweis Kiadó, Budapest

Beunen, G. (2003): Physical growth, maturation and performance. Revista Portuguesa de Ciencias do Desporto, 3: 11-12. https://doi.org/10.5628/rpcd.03.01.03

Bilotta, C., Bowling, A., Nicolini, P., Casé, A., Pina, G., Rossi, S.V., Vergani, C. (2011): Older People's Quality of Life (OPQOL) scores and adverse health outcomes at a one-year follow-up. A prospective cohort study on older outpatients 
living in the community in Italy. Health and Quality of Life Outcomes, 9:72 http://www.hqlo.com/content/9/1/72

https://doi.org/10.1186/1477-7525-9-72

Binder, E. F., Yarasheski, K. E., Steger-May, K., Sinacore, D. R., Brown, M., Scecthmen K. B., Holloszy, J. O. (2005): Effects of progressive resistance training on body composition in frail older adults: results of randomizes controlled trial. The Journals of Gerontology 60A, 11:1425-1431. https://doi.org/10.1093/gerona/60.11.1425

Bodzsár, É. B. (1998): Secular growth changes in Hungary. In: Bodzsár, ÉB, Susanne C. (ed.): Secular growth changes in Europe. Eötvös University Press, Budapest, 175-205.

Bognár J., Gangl J., Konczos Cs., Fügedi B., Geosits B. K., Agócs A. (2010): How are quality of life and preferred values viewed by Hungarian adults? Journal of Human Sport and Exercise, 5:1, 84-93.

https://doi.org/10.4100/jhse.2010.51.09

Bouchard, C. (Eds.) (2000): Physical activity and obesity. Human Kinetics Publishers, Inc., Champaign, Illinois, 3-21., 311-345.

Cress, M. E. (2006): Assessing Physical Performance in Older Adults. In: Poon, ChodzkoZajko, Tomporowski (szerk.), Active living, cognitive functioning and aging. Ageing, Exercise, and Cognition Series. Human Kinetics, Champaign.

Ennis, C. D. (2013): Implementing meaningful, educative curricula, and assessments in complex school environments, Sport Educ Soc. 18(1): 115-120. https://doi.org/10.1080/13573322.2012.707978

Ericsson, I., Karlsson, M.K. (2014): Motor skills and school performance in children with daily physical education in school - a 9-year intervention study. Scand J Med Sci Sports, 24: 273-278. doi:10.1111/j.1600-0838.2012.01458. https://doi.org/10.1111/j.1600-0838.2012.01458.x

Európai Munkahelyi Biztonsági és Egészségvédelmi Ügynökség (2011): Munkahelyi egészségfejlesztés munkavállalók számára. https://osha. europa.eu/ Letöltve: 2018. 03. 12.

Farmosi I., Bakonyi F. (1987): A kondicionális képességek szekuláris változásai. Testnevelés- és Sporttudomány, 3: 20-26.

Feith H. J., Melicher D., Máthé G. et al. (2016): Tapasztalatok es motiváltság: magyar középiskolások véleménye az egészségvédő programokról. Orv. Hetil. 157(Suppl 2): 65-69.

https://doi.org/10.1556/650.2015.30338

Fügedi, B., Capel, S., Dancs, H., Bognár, J. (2016): Satisfaction and preferences of PE students and the head of the PE department: meeting the new curricular expectations. Journal of Human Sport and Exercise. 11:(1) 1-18. https://doi.org/10.14198/jhse.2016.111.01 
Gáldi, G. (2002): Fizikai aktivitás Magyarországon az ezredfordulón. Magyar Sporttudományi Szemle. 3-4. 16.

Halmai R., Németh Á. (2010): Fizikai aktivitás és szabadidős tevékenységek. in Németh Á. - Költő A. (szerk.): Serdülőkorú fiatalok egészsége és életmódja 2010. (HBSC 2010) http://www.ogyei.hu/anyagok/HBSC_2010.pdf. Letöltve: 2017. 01. 30.

Huszár A., Bognár J. (2006): Fiatal felnőttek testkultúrája, avagy az iskolai testnevelés felnőttkori hatásai Magyarország és Finnország példáján. Új Pedagógiai Szemle, 6. 107-114.

Ihász F., Király T., Mészáros J., Kevin, J. F., Szakály Zs. (2005): Comparing the data of body size and body composition for irregularly physically active 9-10 years old pupils. Hungarian Review of Sport Science. 6: (3) 25.

Ihász F., Király T., Szakály Zs. (2012): A keringési rendszer fejlesztésének megújítása Győr város iskoláiban. Magyar Sporttudományi Szemle 13:(50/2) p. 41.

Iván L. (2002): A gerontológia újabb eredményei, az egészséges öregedés esélyei és kockázatai. Hippocrates, 6:381-387.

Iván L. (2008): A gerontológia rendszerszemlélete és gyakorlata. Az öregedési folyamat jellemzői. In: Semsei I. (szerk.), Gerontológia, Nyíregyháza, Start R.V. 37-48.

Király T., Szakály Zs. (2011): Mozgásfejlődés és a motorikus képességek fejlesztése gyermekkorban. Dialóg-Campus Kiadó, Budapest-Pécs.

Konczos Cs., Ihász F., Szakály Zs., Huszár A. (2006): Az egészségtudatos életvitel is megtanulható? Magyar Sporttudományi Szemle 28: (4) 20-23.

Konczos, Cs., Szakály, Zs., Ihász, F. (2011): Health behaviour, body composition and motor performance in female university students Annals of Research in Sport and Physical Activity (2) 22-31.

https://doi.org/10.14195/2182-7087_2_2

Kopkáné P.J. (2013): A rendszeres fizikai aktivitás hatása az idős kori függetlenség megőrzésére 60 év fölötti nők esetében: randomizált kontrollált kísérlet. PhD-disszertáció. Semmelweis Egyetem, Doktori Iskola.

Központi Statisztikai Hivatal (2015): Statisztikai tükör 2015/27. https://www.ksh. hu/docs/hun/xftp/idoszaki/pdf/elettart.pdf. Letöltve 2018. 02. 23.

Központi Statisztikai Hivatal (2017): A születéskor várható átlagos élettartam, átlagéletkor. http://www.ksh.hu/docs/hun/xstadat/xstadat_eves/i_ wdsd008.html. Letöltve 2018. 03. 21.

Központi Statisztikai Hivatal (2018): A 2014-ben végrehajtott Európai Lakossági Egészségfelmérés eredményei Összefoglaló adatok. http://www.ksh.hu/ docs/hun/xftp/idoszaki/elef/elef2014_osszefoglalo.pdf. Letöltve: 2018. 02. 03. 
Majercsik E. (2008): Életminőség és közérzet az élet alkonyán. Magyar Családorvosok Lapja, 7: 6-10.

Malina, R. M., Bouchard, C. (1991): Growth, Maturation, and Physical Activity. Human Kinetics Books, Champaign, Illinois.

McKechine, R., Mosca, L. (2003): Activity and coronary Heart disease prevention and effect on risk factors, Cardiol-Rev, Jan-febr. 11(1):21-5 https://doi.org/10.1097/00045415-200301000-00005

Mészáros Zs., Vajda I., Mészáros J., Photiou A., Zsidegh M. (2006): Leányok testösszetétel- és motorikus teljesítményváltozása. Sportorvosi Szemle, 47: 62.

Mészárosné L. (2008): Az idősek komplex mozgásprevenciója. In: Semsei I. (szerk.) Gerontológia, Nyíregyháza: Start R.V. 493-503.

Mikulán R. (2013): Az iskolai testnevelés szerepe és jelentősége az egészségfejlesztésben. http://folyoiratok.ofi.hu/uj-pedagogiai-szemle/ az-iskolai-testneveles-szerepe-es-jelentosege-az-egeszsegfejlesztesben. Letöltve: 2018. 01. 30.

Molnár D., Erhardt É., Felső R. (2017): Gyermekkori elhízás: prevenció és kezelés. In: Bedros J. R. (ed.) Klinikai Obezitológia, Egyetemi Tankönyv, Semmelweis Kiadó.

Mura, G., Rocha, N. B., Helmich, I., et al. (2015): Physical activity interventions in schools for improving lifestyle in European countries 2015. https://www. ncbi.nlm.nih.gov/pubmed/25834629 Letöltve: 2017. 07. 24.

Olvasztóné Balogh Zsuzsanna, Bognár József, Gangl Judit, Polgár Tibor, Fügedi Balázs (2007): Felnőttek érték- és tevékenységrendszerének feltárása. Egészségfejlesztés, 48:5-6, 7-13.

Olvasztóné Balogh Zsuzsanna, Bognár József, Barthalos István, Kopkáné Plachy Judit, Ráczné Németh Teodóra (2012): Quality of life, assertiveness, and personality dimensions in elderly men. Biomedical Human Kinetics, 4. 88-92. https://doi.org/10.2478/v10101-012-0016-y

Pál Katalin, Császár Judit, Huszár Aanikó, Bognár József (2005): A testnevelés szerepe az egészségtudatos magatartás kialakításában. Új Pedagógiai Szemle, 55:6, 25-32.

Photiou, A., Anning, J., Mészáros, J., Vajda, I., Mészáros, Zs., Sziva, Á., Prókai, A., Ng, N. (2008): Lifestyle, body composition and physical fitness changes in Hungarian school boys (1975-2005). Research Quarterly for Exercise and Sport, 79: 168-173. https://doi.org/10.1080/02701367.2008.10599480

Poon, L. W., Chodzko-Zajko, W. J., Philip, D. T. (2006): Active living, cognitive functioning and aging. Ageing, Exercise, and Cognition Series. Human Kinetics, Champaign, 22-55. 
Post, G. B., Kemper, H. C. G., Twisk, J. W. R. (1997): Biological maturation in relation to lifestyle from adolescence into adulthood. In: Armstrong, N., Kirby, B. J., Welsman, J. R. (Ed.). Children and exercise XIX. Promoting health and well-being. E. and F.N. SPON, London, 57-62.

Rankinen, T., Perusse, L., Bouchard, C. (2001): Genetic aspects of physical activity, cardiorespiratory fitness and the response to regular exercise. In: Hollmann W, Kurz D, Mester J. (Eds.): Current results on health and physical activity, Series Club of Cologne, Hofmann-Schattauer-Verlag, 2: 27-60.

Ross, R., Janssen, I., Tremblay, A. (2000): Obesity reduction through lifestyle modification. Canadian Journal of Applied Physiology, 1: 1-18. https://doi.org/10.1139/h00-001

Rowland, T. (2003): Effects of body fat on cardiovascular fitness in youth. Revista Portuguesa de Ciencias do Desporto, 3: 18-19. https://doi.org/10.5628/rpcd.03.01.03

Rurik I., Ungvári T., Szidor J., Torzsa P., Móczár Cs., Jancsó Z., Sándor J. (2016): Elhízó Magyarország. A túlsúly és az elhízás trendje és prevalenciája Magyarországon, 2015. Orvosi Hetilap, 157 (31): 1248-1255. https://doi.org/10.1556/650.2016.30389

Salem, G. J., Skinner, J. S., Chodzko-Zajko, W. J., Proctor, D. N., Fiatarone, S., Maria, A., Minson, C. T., Nigg, C. R. (2009): Exercise and Physical Activity for Older Adults. Medicine \& Science in Sports \& Exercise, 41:1510-1530. https://doi.org/10.1249/MSS.0b013e3181a0c95c

Shephard, R. J., Trudeau, F. (2000): The legacy of physical education: influences on adult lifestyle. Paediatr Exerc Sci. 1: 34-50. https://doi.org/10.1123/pes.12.1.34

Strong, W. B. et al., (2005): Evidence based physical activity for school-age youth. The Journal of Pediatrics, 146, 732-737.

https://doi.org/10.1016/j.jpeds.2005.01.055

Szakály Zs., Búza L. (1994): Serdülőkorú középiskolások 12 perces futóteljesítményének elemzése a testalkatés a szívfrekvencia viszonylatában. TF szakdolgozat, Budapest

Szakály Zs., Pozsgai P. (2000): Egy fizikai felmérés tapasztalatai a Bercsényi Miklós Gimnázium és Közlekedési Szakközépiskolában. Magyar Sporttudományi Szemle. 1: (3-4) 19-21.

Szakály Zs. (2002): Physique, body composition and motor performances in college students. Hungarian Review of Sport Science. Special Issue, 24-29.

SzakályZs., Ihász F., KirályT., Murai B., Konczos Cs. (2003): Testalkat, testösszetétel és az aerob teljesítmény hosszmetszeti vizsgálatának tapasztalatai női főiskolai hallgatóknál. Magyar Sporttudományi Szemle. 3: (1) 30-32. 
Szakály Zs., Mészáros Zs., Mészáros J., Photiou A., Prókai A., Vajda I., Nelson Ng., Shuzo K. (2007): Changes of Four Years in Body Composition and Oxigen Uptake of Young Adults Males after University Graduation. Journal of Physiological Antropology. Vol.26. No.4. 437-441. https://doi.org/10.2114/jpa2.26.437

Szakály Zs. (2008): Testalkat, testösszetétel és motorikus teljesítmény-jellemzők vizsgálata. PhD-disszertáció, Semmelweis Egyetem.

Szakály Zs., Liszkai Zs., Lengvári B., Konczos Cs. (2015): Antropometriai jellemzők és állóképességi teljesítmények 7-14 éves fiúknál Nyugat-Magyarországon Magyar Sporttudományi Szemle 16:(64) 19-25.

Szakály Zs., Ihász F., Konczos Cs., Plachy J., Bognár J., Kolomiets O. (2016): Physique, body composition and motor performances in Hungarian students. Uchenie Zapiski Universiteta Imeni p. f. Lesgafta. (3) 267-274.

Szakály, Zs., Bognár, J., Barthalos, I., Ács, P., Ihász, F., Fügedi B. (2016): Specific heart rate values of 10-12-year-old physical education students during physical activity. Journal of Physical Education and Sport 16:(3) 800-805.

Szakály, Zs., Ihász, F., Konczos, Cs., Fügedi, B., Bognár J. (2016): Body composition and the level of fitness in 10 to 14-year-old girls in western Hungary: the impact of the new PE curriculum. Biomedical Human Kinetics (8) 95-102. https://doi.org/10.1515/bhk-2016-0014

Székács B. (2005): Geriátria, az időskor gyógyászata. Budapest, Semmelweis Kiadó, 487.

Tammelin, T., Nayha, S., Hills, P., Jarvelin, M.R. (2003): Adolescent participation in sports and adult physical activity. Am J Prev Med. 24(1):22-8. https://doi.org/10.1016/S0749-3797(02)00575-5

Tánczos Zoltán, Bognár József (2019): A személyi edzői hivatás tudományos és szakmai aspektusai. Egészségfejlesztés, 60:1, 45-50.

Telama, R., Yang, X. (2000): Decline of physical activity from youth to young adulthood in Finland. Medicine and Science in Sports and Exercise, 9:16171622.

https://doi.org/10.1097/00005768-200009000-00015

Tóth G. A., Eiben O. G. (2004): Secular changes of body measurements in Hungary. Humanbiologia Budapestinensis, 28: 7-72.

Túri S. et al. (2017): Epidemiológiai vizsgálatok elhízott gyermekekben. In: Bedros JR (ed.) Klinikai Obezitológia, Egyetemi Tankönyv, Semmelweis Kiadó.

Vécseyné Kovách Magdolna, Plachy Judit, Bognár József (2008): A felnőttek egészséges, aktív életmódja - összehasonlító előtanulmány a fiatal felnőttek és idős korosztály életmódjáról, rendszeres fizikai aktivitásáról. ACTA ACADEMIAE PAEDAGOGICAE AGRIENSIS NOVA SERIES: SECTIO SPORT 35, 107-115. 
Vuori, I. (1998): Does physical activity anhance health? Patient Education and Counselling, 33:595-S10 https://doi.org/10.1016/S0738-3991(98)00014-7

Vuori, I. (2004): Physical activity as a disease risk and health benefits of increased physical activity. In Pekka Oja and Jan Borms (Eds.). Perspectives. The multidisciplinary series of physical education and sport science. Meyer and Meyer Sport, Berlin 29--96.

Zhang, M., Xie, X., Lee, A. H., Binns, C. W. (2004): Sedentary and behaviors and epithelial ovarian cancer risk. Cancer Couses Control, 15 (1):83-9.

https://doi.org/10.1023/B:CACO.0000016633.47025.2a

\section{Levelező szerző:}

Dr. Szakály Zsolt

Széchenyi István Egyetem, Győr

szakaly.zsolt@sze.hu 